FULL RESEARCH ARTICLE

\title{
Status of the Amargosa niterwort (Amaranthaceae) in California and Nevada
}

\author{
NAOMI SUZANNE FRAGA*1, ALICE L. MILLER ${ }^{2}$, SARAH J. DE \\ GROOT $^{1}$, COREY LEE $^{3}$, CHRISTINA L. LUND $^{4}$, AND KARA MOORE- \\ O'LEARY $^{5}$
}

${ }^{1}$ California Botanic Garden, 1500 North College Avenue, Claremont, CA 91711, USA

${ }^{2}$ Pyramid Botanical Consultants, 3001 Carriage Drive Estes Park, CO 80517, USA

${ }^{3}$ U.S. Fish and Wildlife Service Ash Meadows National Wildlife Refuge 8757 E. Spring Meadows Road S. Amargosa Valley, NV 89020, USA

${ }^{4}$ Bureau of Land Management, California State Office, 2800 Cottage Way Sacramento, CA 95825, USA

${ }^{5}$ U.S. Fish and Wildlife Service, Pacific Southwest Region, 3020 State University Drive East Modoc Hall Suite 2007, Sacramento, CA 95819, USA

*Corresponding Author: nfraga@calbg.org

The Amargosa niterwort is a narrow endemic restricted to alkali wetlands of the northern Mojave Desert in Inyo County, California and Nye County, Nevada. Groundwater pumping and subsequent hydrological alteration within the Amargosa groundwater basin has been identified as the most significant threat to the long-term persistence of the species. Parallel monitoring programs were established in California (2010) and Nevada (2014) to establish baseline trends in abundance, measured as ramet (stem) number, and to aid in determining management actions that are needed to ensure the long-term viability of populations. Monitoring in California shows significant variation in abundance between years; however, there are consistent trends, indicating that factors influencing increase or decrease in abundance is similar across the population. However, this pattern is not shared in Nevada, where following a sharp decline between 2014 and 2015 the population has remained relatively stable. Two of the three Nevada macroplots are downstream from Crystal Reservoir and are likely influenced by discharge from the reservoir including periodic water releases and leakage from the earthen dam. Significant increases and decreases in abundance within macroplots are not correlated with climate variables including precipitation, thus it is important to understand how groundwater flow and spring discharge impacts abundance of plants within and between populations. 
Key words: alkali wetland, Amaranthaceae, Amargosa niterwort, Nitrophila mohavensis, Mojave Desert, rare plant monitoring

The very narrow global range and specific habitat requirements of Nitrophila mohavensis Munz \& J.C. Roos (Amargosa niterwort) make it vulnerable to extinction (USFWS 2007). As such, implementing research and monitoring are essential to understanding its status and to inform management actions and conservation strategies to advance recovery. Here we describe ongoing research, monitoring, and management activities that have been conducted or are in progress, including a cross-border initiative to share results and develop range-wide conservation strategies.

Nitrophila mohavensis is a narrow endemic restricted to the Amargosa River basin in the northern Mojave Desert in Inyo County, California and Nye County, Nevada (Fig. 1). It occurs on land managed by the Bureau of Land Management (BLM), Ash Meadows National Wildlife Refuge (AMNWR), and private land (USFWS 2007). It is an herbaceous rhizomatous perennial in the Amaranthaceae (amaranth family) that forms dense colonies of erect stems that are low to the ground and die back to an underground rhizome in the winter. The flowers are pink, relatively small (2-3.5 mm; Wetherwax et al. 2012), and located singly in the leaf axils. Nitrophila mohavensis was first described in 1955 from specimens collected at lower Carson Slough in Inyo County, California, at the time of its description N. mohavensis was considered "locally abundant in heavily alkaline mud" (Munz and Roos 1955). It was listed as endangered under the California Endangered Species Act in 1978, by the U.S. Fish and Wildlife Service (USFWS) under the Federal Endangered Species Act in 1985, and by the state of Nevada in 1986 due to habitat alteration from agriculture, groundwater pumping, and water diversion (USFWS 2007; CNPS 2020; NatureServe 2020).

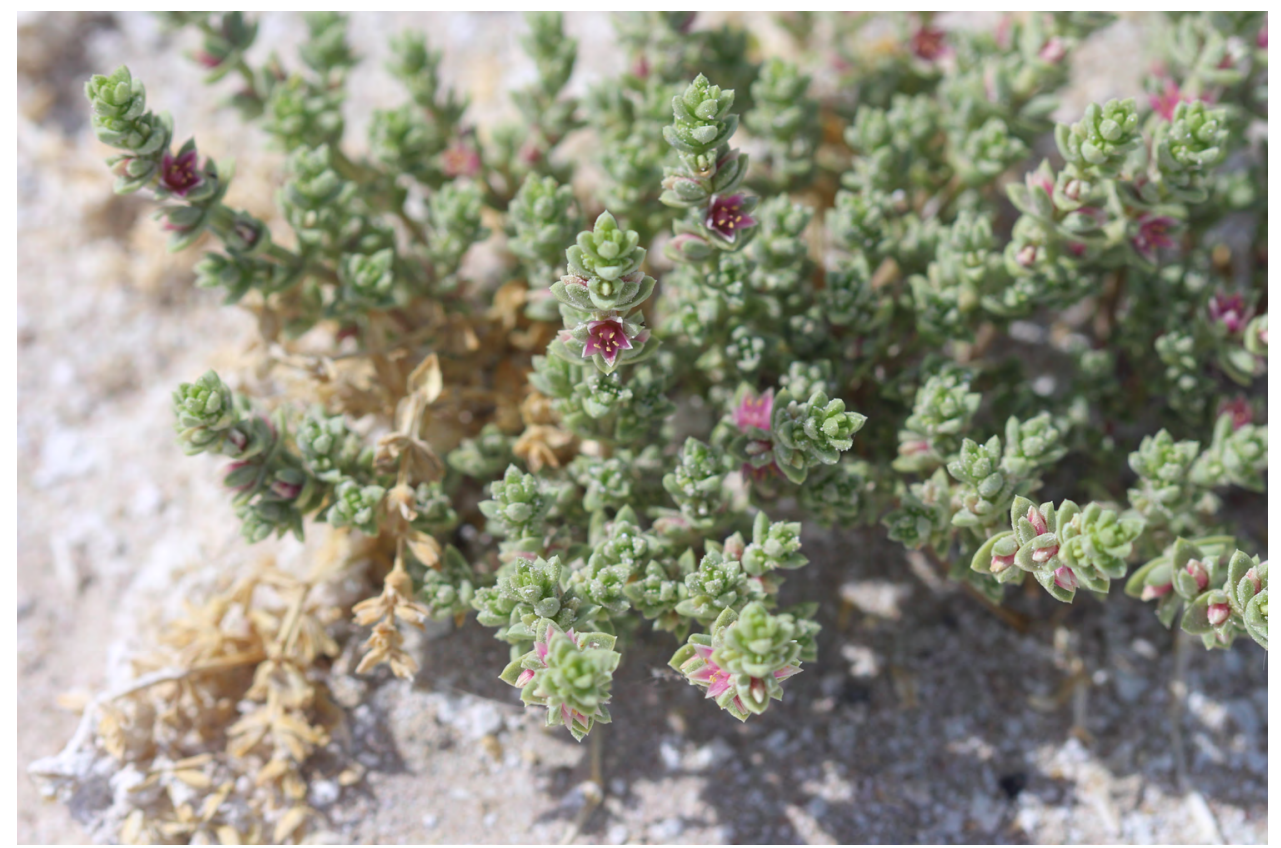

Figure 1. Amargosa niterwort in flower on lower Carson Slough, Inyo County, California. 


\section{Distribution and Abundance}

There are four primary locations where $N$. mohavensis occurs: 1) Soda Springs, NV, 2) AMNWR, NV, 3) lower Carson Slough, CA, and 4) Tecopa Hot Springs, CA (Fig. 2). Based on delineations outlined by the USFWS (2020), it is currently known to occur at 14 occurrences across its range: 12 occurrences in Nevada and two in California. The lower Carson Slough occurrence in Inyo County, California is the largest known occurrence in terms of total population size (USFWS 2020); this holds true, even if all of the Nevada occurrences

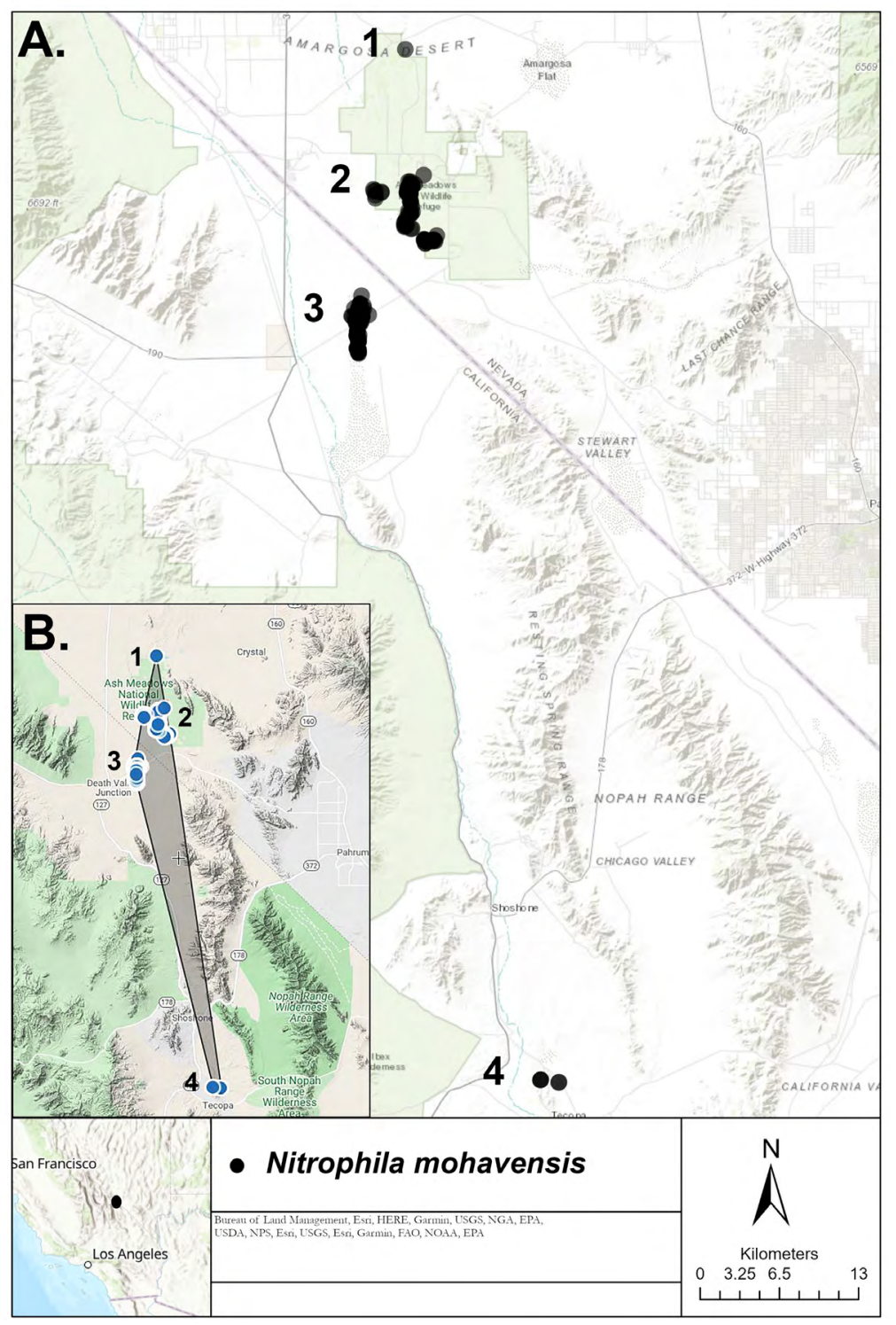

Figure 2. A. Range-wide distribution map of Amargosa niterwort. B. Convex hull encompassing the 185-points that represent the known global distribution of these species. Population 1. Soda Spring; Population 2. Ash Meadows NWR; Population 3. Lower Carson Slough; Population 4. Tecopa Hot Springs. 
are treated as one site (Table 1; Fig. 2). At the time of initial listing, N. mohavensis was thought to be restricted to lower Carson Slough in California, however it was documented in Tecopa Hot Springs as early 1963, based on an herbarium specimen collected by L.C. Wheeler (8409 [RSA], CCH2 2020). Mary DeDecker reported the occurrence at Tecopa Hot Springs to regulatory agencies in 1986 (CNDDB 2020). Nitrophila mohavensis was first documented at AMNWR in 1984 and it has since been mapped throughout the Refuge more extensively (USFWS 2007; 2020). A previously unknown patch of $N$. mohavensis was recently documented on BLM land in Nevada in 2019 and extends the Nevada Carson Slough occurrence by $300 \mathrm{~m}$ west of the AMNWR boundary (Lara Kobelt, Bureau of Land Management personal communication).

Table 1. Known locations for Amargosa niterwort in California and Nevada. Global population estimates are from 2009 to 2017 (USFWS 2020), extent of occurrence was calculated as a part of this study.

\begin{tabular}{llllrc}
\hline Population & State & Site Name & Land Ownership & $\begin{array}{l}\text { Global } \\
\text { Population } \\
\text { Estimate }\end{array}$ & $\begin{array}{l}\text { Extent of } \\
\text { occurrence } \\
\left(\mathrm{km}^{2}\right)\end{array}$ \\
\hline 1 & NV & Soda Spring & AMNRW & 3,993 & $\sim 5 \mathrm{~m}^{2}$ \\
2 & NV & Ash Meadows NWR & AMNRW & 54,299 & 16.02 \\
3 & CA & Lower Carson Slough & BLM & 176,886 & 3.44 \\
4 & CA & Tecopa Hot Springs & BLM/Private & 470 & 0.04 \\
& & Total Global Estimation & & 235,648 & 19.5 \\
\hline
\end{tabular}

Habitat

Nitrophila mohavensis is restricted to salt encrusted soils in sparsely vegetated, alkaline wetlands, in flat open areas that are exposed to full sun, between $400 \mathrm{~m}(1,300 \mathrm{ft})$ to $700 \mathrm{~m}(2,300 \mathrm{ft})$ in elevation (CCH2 2020; CNDDB 2020). The soil has been described as finely textured silts and clay with little internal drainage (Hasselquist and Allen 2009), but also as sandy loam (57\% sand), with a pH ranging from 8.4 (Johnston and Zink 2004) to 9.6 (DeFalco et al. 2017). The moisture level of the soil within occupied habitat has been described as moist to saturated, with the soil being subject to perennial moisture due to the presence of a high groundwater table (USFWS 2007; Hasselquist and Allen 2009; DeFalco et al. 2017). Nitrophila mohavensis forms the dominant component of the vegetation where it occurs and is associated with Atriplex confertifolia (Torr. \& Frém.) S. Watson (shadscale, Chenopodiaceae), Chloropyron tecopense (Munz \& J.C. Roos) Tank \& J.M. Egger (Tecopa bird's beak, Orobanchaceae), Cleomella brevipes S. Watson (shortstalk stinkweed, Cleomaceae), Distichlis spicata (L.) Greene (saltgrass, Poaceae), Nitrophila occidentalis (Moq.) S. Watson (borax weed, Amaranthaceae), and Suaeda nigra (Raf.) J.F. Macbr. (bush seepweed, Chenopodiaceae, USFWS 2007; CCH2 2020; CNDDB 2020).

Using an isotopic analysis of transpired water, Hasselqust and Allen (2009) found that $N$. mohavensis accesses water near the soil surface in the early spring and hot summer months as opposed to accessing water from greater depths $(>30 \mathrm{~cm})$, indicating that groundwater upwelling, surface water from spring outflows, and precipitation may all be important sources of soil moisture. This is consistent with a separate study that found $N$. mohavensis habitat had lower soil salinity and higher soil moisture content compared with adjacent saltgrass (D. spicata) and mixed shrub habitat. In addition, there was no evidence of interspecific competition between N. mohavensis and D. spicata by DeFalco et al. (2017). 
However, given the extensive distribution of D. spicata within N. mohavensis habitat, the potential for competition should be investigated further.

\section{Reproductive Biology}

A population genetic study of microsatellite loci sampled 178 individuals across the range of $N$. mohavensis and found evidence of sexual and asexual reproduction (Martin et al. 2013). Asexual clonal reproduction can occur when ramets (stems) arise from a genet's (genetic individual's) extensive network of rhizomes, but evidence for multiple genotypes within dense patches of plants, suggests that clusters of ramets could consist of more than one genet (Martin et al. 2013). A total of 32 of 78 recovered multi-locus genotypes were sampled from more than one individual, providing evidence of clonal reproduction. Three genotypes were collected from 22 samples across the range of the species (a maximum distance of more than $50 \mathrm{~km}$ ), indicating that clones can disperse a relatively long distance (Martin et al. 2013). Mechanisms for dispersal have not been investigated, but stems could disperse long distance during large flood events. A combination of sexual and asexual reproduction is further substantiated by DeFalco et al. (2017), who found shifts from clonal to sexual reproduction in plants that were transplanted into adjacent saltgrass (D. spicata) habitat. Pollinators of $N$. mohavensis have not been documented, but ants and wind have been suggested as pollen dispersal mechanisms (Tanner et al. 2012).

\section{Threats}

Numerous threats are known to impact or have potential to impact plants and habitat of $N$. mohavensis including groundwater pumping, hydrological alteration, off-highway vehicle incursion, road creation and maintenance, trampling by feral horses, development, and climate change (USFWS 1983, 1990, 2007). Groundwater pumping and subsequent hydrological alteration within the Amargosa groundwater basin has been identified as the most significant threat to the long-term persistence of the species (USFWS 1990). Eleven piezometers were installed in 2009 at lower Carson Slough in Inyo County, California to monitor the shallow groundwater because of the importance of maintaining high soil moisture.

In 1998 it was observed that road construction and realignment along State Line Road directly impacted plants and habitat at the lower Carson Slough occurrence in California. At this occurrence, the road is raised above ground level creating a berm-like barrier, impeding water transport on the other side of the road (south), thus altering habitat. State Line Road bisects the most abundant occurrence of $N$. mohavensis and provides an access point for off-highway vehicle incursion and thus remains a significant threat to the species.

\section{METHODS}

\section{Population Surveys}

We conducted surveys for N. mohavensis between 2018 and 2020 at lower Carson Slough, and Tecopa Hot Springs in Inyo County, California to determine the current extent and range of the species in California as a part of a Traditional Section 6 Grant (P1886001) issued by the USFWS. Surveys took place between the months of April and July when $N$. mohavensis is most likely to be in flower and stems are green (Fig. 3). Latitude and longitude 
were recorded using a GPS unit when plants were found. An effort was made to identify and map the edges of the population at lower Carson Slough to develop a more accurate map of the population boundary (Fig 2). Comprehensive surveys were also conducted at AMNWR between 2007 and 2009. The current survey effort to map N. mohavensis in California will continue until 2022. To establish the area of occupancy, the range-wide extent of occurrences was calculated by creating a convex hull around 185-points that represent the known global distribution of these species in ArcGIS Pro 2.4.0 ((c)2019 Esri Inc.; Fig. 2). The point dataset is based on GPS-data collected during the above population surveys in 2018, 2019, and 2020 in California and data provided by Nevada Natural Heritage Program in 2019 and Lara Kobelt in 2019 for Nevada. Extent of occurrence was calculated individually for each of the four known population areas using the same method, by creating individual convex hulls around the four areas rather than the entire group (Table 1; Fig. 2). Area of occupancy was calculated for the global range of the species using the 185-point layer and creating a 10m buffer around each point. A voucher specimen was collected at lower Carson Slough to verify the species identification and document the target species for surveys (Fraga 6371, RSA).

\section{Population Monitoring}

California monitoring.-A pilot monitoring program was established by John Willoughby (retired BLM, independant) for BLM in California in 2010 at lower Carson Slough, with data collected at 23 belt transects that were established across five macroplots. CA macroplot 4 is monitored by taking a total census in a $30 \mathrm{~m} \times 20 \mathrm{~m}$ area and does not have numbered belt transects (Table 2). In 2011 five belt transects were added to CA macroplot 1 and two belt transects added to CA macroplot 3 to increase sampling power, for a total of

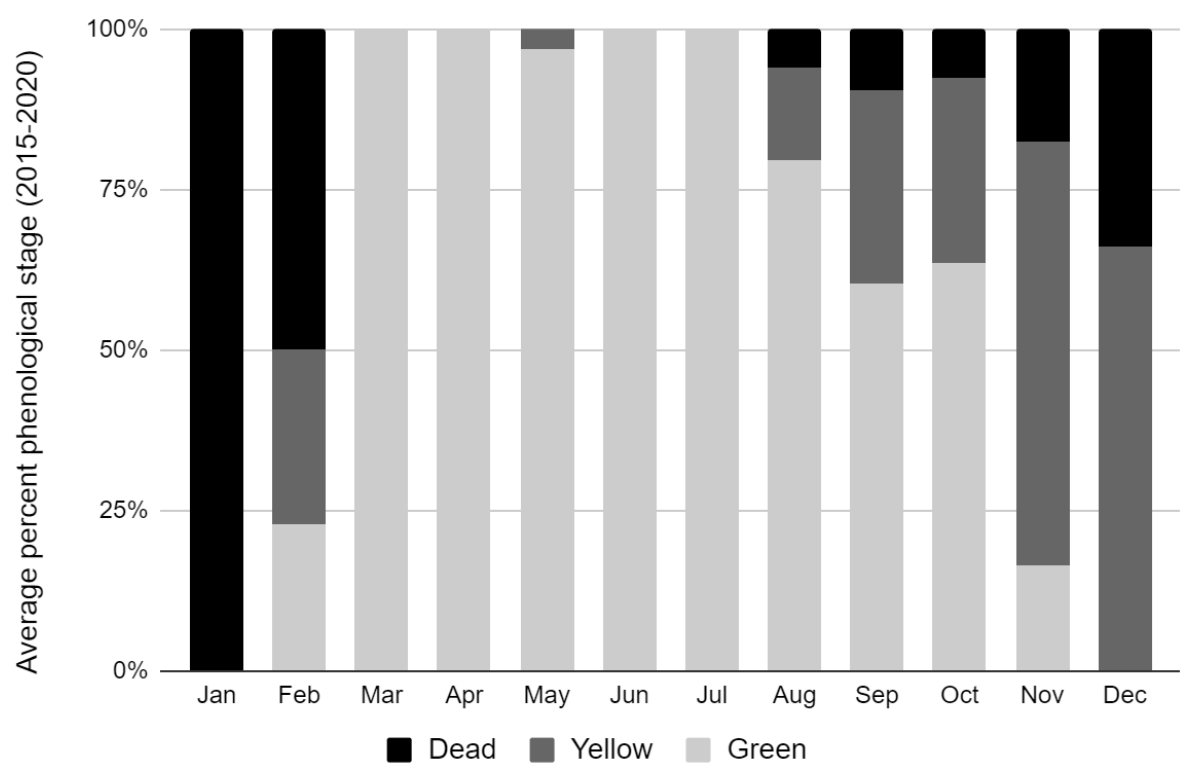

Figure 3. Phenology of Amargosa niterwort from phenological states recorded in two $0.5 \mathrm{~m} \mathrm{x} 1 \mathrm{~m}$ growth plots between 2015 and 2019 at lower Carson Slough in CA. The data reported are averaged percentages. 
30 belt transects that have been monitored between 2011 and 2020 (Table 2). Belt transects are 0.5 meters wide and range in length from $75 \mathrm{~m}$ (macroplots 1,2 , and 5) to $100 \mathrm{~m}$ (macroplot 3). Monitoring did not take place in California in 2012, 2013, and 2014 due to low rainfall, except data were collected for CA macroplot 4 in 2014. In California, monitoring took place in early September in 2010 and late August in 2011, but the monitoring date was moved to July in 2015 to correspond with maximum growth (Fig. 3). Data collected in 2010 is not included in the results because fewer belt transects were measured and the data are not comparable to other years.

Table 2. Summary of Nitrophila mohavensis macroplots (*5 in 2010; **8 in 2010).

\begin{tabular}{ccccccc}
\hline $\begin{array}{c}\text { Macroplot } \\
\text { ID }\end{array}$ & State & Protocol & $\begin{array}{c}\text { Number of } \\
\text { Transects }\end{array}$ & $\begin{array}{c}\text { Transect } \\
\text { Length }(\mathrm{m})\end{array}$ & $\begin{array}{c}\text { Transect } \\
\text { width }(\mathrm{m})\end{array}$ & $\begin{array}{c}\text { Years } \\
\text { Monitored }\end{array}$ \\
\hline CA1 & CA & Belt transect & $10^{*}$ & 75 & 0.5 & $2010-2020$ \\
CA2 & CA & Belt transect & 5 & 75 & 0.5 & $2010-2020$ \\
CA3 & CA & Belt transect & $10^{* *}$ & 100 & 0.5 & $2010-2020$ \\
CA4 & CA & Belt transect & 60 & 20 & 0.5 & $2010-2020$ \\
CA5 & CA & Belt transect & 5 & 75 & 0.5 & $2010-2020$ \\
CN & NV & Belt transect & 10 & 100 & 0.5 & $2014-2020$ \\
NS & NV & Belt transect & 10 & 100 & 0.5 & $2014-2020$ \\
CP & NV & Quadrats & 24 quadrats & 15 & 0.5 & $2014-2020$ \\
\hline
\end{tabular}

Nevada monitoring.-A complementary monitoring program was established at AMNWR in 2014 and includes three macroplots. Two macroplots (CN and NS) consist of ten $0.5 \times 100 \mathrm{~m}$ belt transects that follow the same protocol as in California; the third macroplot $(\mathrm{CP})$ measures abundance in 24 permanently marked $15 \times 0.5 \mathrm{~m}$ quadrats (Table 2). In Nevada, monitoring takes place in June and July to correspond with peak flowering time. Data were collected from 2014 to 2020, but not in 2017 within the Nevada monitoring plots.

Because N. mohavensis is rhizomatous, counting individual ramets is difficult without damaging plants, therefore ramets (herein referred to as clumps) were defined as a unit that includes groups of stems that are separated by less than $2 \mathrm{~cm}$ from each other from the point at which they are rooted. The unit of the "clump" is used in California and Nevada to measure abundance. The total number of clumps are counted in each cell $(0.5 \mathrm{~m}$ wide $\mathrm{x}$ $1 \mathrm{~m}$ length) along the entire length of each belt transect. Differences in abundance within macroplots using belt transects as paired sampling units between years was tested using Wilcoxon signed rank test (Table 3).

\section{Phenology Monitoring}

Five $1 \mathrm{~m}$ x $0.5 \mathrm{~m}$ plots were established in 2012 and monitored monthly until 2019 at lower Carson Slough, Inyo County, California to increase understanding of phenology. However, plants appear to have died in three of the five plots between 2015 and 2019, so phenology is only presented from two plots. Descriptions of phenological stages were recorded, including stem color or condition (green, yellow, dormant), clump size (length and width), number of clumps, and the presence of flowers or fruits. Phenological results are presented as the average percentage of observed green, yellow or dormant clumps for each month between 2015 and 2019 (Fig. 3). 
Table 3. A. Wilcoxon signed rank test comparing the abundance of Amargosa niterwort in two macroplots with belt transects in Nevada (NV) between two years. B. Wilcoxon signed rank test comparing the abundance of Amargosa niterwort in four macroplots in California (CA) between two years. Wilcoxon signed rank test statistics are reported. $* \mathrm{P}<0.05, \mathrm{ND}=$ no data

A.

\begin{tabular}{lccccc}
\hline Macroplot & $\mathbf{2 0 1 4 - 2 0 1 5}$ & $\mathbf{2 0 1 5 - 2 0 1 6}$ & $\mathbf{2 0 1 6 - 2 0 1 8}$ & $\mathbf{2 0 1 8 - 2 0 1 9}$ & $\mathbf{2 0 1 9 - 2 0 2 0}$ \\
\hline NV CN & 24 & 19 & 10 & 18 & 9 \\
NV NS & 27 & 9 & 21 & ND & 9
\end{tabular}

B.

\begin{tabular}{lcccccc}
\hline Macroplot & 2011-2015 & $\mathbf{2 0 1 5 - 2 0 1 6}$ & $\mathbf{2 0 1 6 - 2 0 1 7}$ & $\mathbf{2 0 1 7 - 2 0 1 8}$ & $\mathbf{2 0 1 8 - 2 0 1 9}$ & $\mathbf{2 0 1 9 - 2 0 2 0}$ \\
\hline CA1 & 21 & $8^{*}$ & $0^{*}$ & 17 & 10 & 14 \\
CA2 & 4 & $0^{*}$ & $0^{*}$ & 6 & $0^{*}$ & $0^{*}$ \\
CA3 & 10 & $7^{*}$ & $8^{*}$ & 21 & $0^{*}$ & 22 \\
CA5 & 4 & 4 & $0^{*}$ & $0^{*}$ & 3 & $0^{*}$ \\
\hline
\end{tabular}

\section{Climate Data}

Annual cumulative precipitation, mean daily temperature, mean daily minimum temperature, mean daily maximum temperature, and 30-year normals for each of the above variables were downloaded for Lower Carson Slough in Inyo County California from the (PRISM 2020). The climate variables were also downloaded for Crystal Reservoir in Nye County, Nevada. The Nye County data provided the same results in the statistical analyses, so they were not included here. The normals are baseline datasets describing average monthly and annual conditions over the most recent three full decades and cover the period 1981-2010. These data were summarized for the growing season of $N$. mohavensis, which is consistent with the hydrological year (also known as water year), defined as precipitation from October of the prior year through September of the next year. Correlations between annual precipitation and recorded $N$. mohavensis abundance based on monitoring data were assessed using Pearson correlation coefficient (parametric) and Spearman rank correlation coefficient (non-parametric; Table 4) because it was not clear if the data were normally distributed.

\section{Seed Collection}

Seeds were sampled at lower Carson Slough in California in 2010, 2011, and 2020 to establish long-term germplasm collections in off-site and secure storage. Collections were made according to standard methods approved by the Center for Plant Conservation (CPC 2017 ) with no more than $5 \%$ of a population's annual seed output collected. Individuals were selected randomly throughout the population to capture genetic diversity and maternal lines were collected and stored separately for the collection made in 2020. Individual seed samples were cleaned, processed, and checked for viability at the California Seed Bank at California Botanic Garden in Claremont, California. Viability was assessed using nondestructive methods due to limited seed quantity by visually examining seeds to determine if they were full. Seeds were dried in a desiccation chamber until they reached $13 \%$ relative humidity. After the drying period, seeds were placed into foil/plastic laminate storage pouches that were heat-sealed and placed into freezers at $-18^{\circ} \mathrm{C}$. Germination trials were not 
Table 4. Pearson's correlation coefficient ( $r)$ and Spearman rank correlation coefficient $\left(r_{s}\right)$ values comparing climate variables and abundance in California and Nevada. ${ }^{*} \mathrm{p}<0.05$.

\begin{tabular}{lcccc}
\hline & $\begin{array}{c}\text { r CA Total } \\
\text { Abundance }\end{array}$ & $\begin{array}{c}\text { r NV Total } \\
\text { Abundance }\end{array}$ & $\begin{array}{c}\mathrm{r}_{\mathrm{S}} \text { CA Total } \\
\text { Abundance }\end{array}$ & $\begin{array}{c}\mathrm{r}_{\mathrm{S}} \text { NV Total } \\
\text { Abundance }\end{array}$ \\
\hline Total Precip $(\mathrm{cm})$ & 0.402 & -0.371 & 0.321 & -0.086 \\
Tmin $(\mathrm{C})$ & -0.091 & 0.285 & 0.143 & 0.2 \\
Tmean(C) & -0.356 & 0.356 & -0.143 & 0.486 \\
T $\max (\mathrm{C})$ & -0.539 & 0.397 & -0.464 & 0.486 \\
\hline
\end{tabular}

performed because seed quantities were too small (e,g, there was an average of two seeds per maternal line in the 2020 collection).

\section{RESULTS}

\section{Distribution and Abundance}

Based on survey data, the global extent of occurrence, or the smallest continuous area that can be drawn to encompass all known sites for $N$. mohavensis, is estimated to be 39,409 ha (394.09 km², 97,382 acres; Fig. 2). If we consider each of the four known populations separately, the extent of occurrence is $1,950 \mathrm{ha}\left(19.5 \mathrm{~km}^{2}, 4,819\right.$ acres $)$ when convex hulls are calculated individually for each population and the areas summed (Table 1). The area of occupancy, or the area within the extent of occurrence that is known to be occupied is estimated to be 9 hectares $\left(0.9 \mathrm{~km}^{2}, 222\right.$ acres). Plants on private property in Tecopa Hot Springs appear be extirpated due to development based on surveys conducted in 2018, 2019 and 2020, although plants in Tecopa Hot Springs remain extant on land managed by BLM.

California monitoring.- In California, there is variation in the abundance of clumps between years within all macroplots, but the pattern of variation (increase and decrease within a macroplot) is consistent across all macroplots starting in 2015. There was a large and significant increase in abundance in CA macroplot 1 between the years of 2015 to 2016 and 2016 to 2017 (Table 3). Between 2015 and 2020 CA macroplot 1 accounted for 70-78\% of all clumps counted in the CA macroplots, and thus is an important driver of the pattern of abundance for the cumulative total of clumps in all CA macroplots (Fig. 4). There was an increase in the number of clumps across all macroplots between 2015 and 2016, but there was only a significant increase in the abundance of clumps in CA macroplots 1-3 (Table 3 ). There was a significant increase in the number of clumps across all macroplots between 2016 and 2017 (1-5; Table 3). There was a decrease in the number of clumps across all macroplots between 2017 and 2018, but this difference was only significant in CA macroplot 5. CA macroplot 5 has the fewest number of clumps compared to all other macroplots; it is located on the south side of State Line Road, where plants are less abundant. 2020 had the highest number of clumps recorded for all macroplots across all monitored years except for macroplot 4, which was most abundant in 2011 (1,439 clumps).

Nevada monitoring.- In Nevada, there was a decline in N. mohavensis abundance over the monitoring survey period (2014-2020; Fig. 4). This decline is primarily the result of the sharp decline at $\mathrm{CP}$ between 2014 and 2015. Abundance remained stable over the monitoring period at other macroplots, and at CP after 2015 (Table 3; Fig. 4). Abundance trends at the three macroplots in Nevada did not follow a consistent pattern. Abundance at 


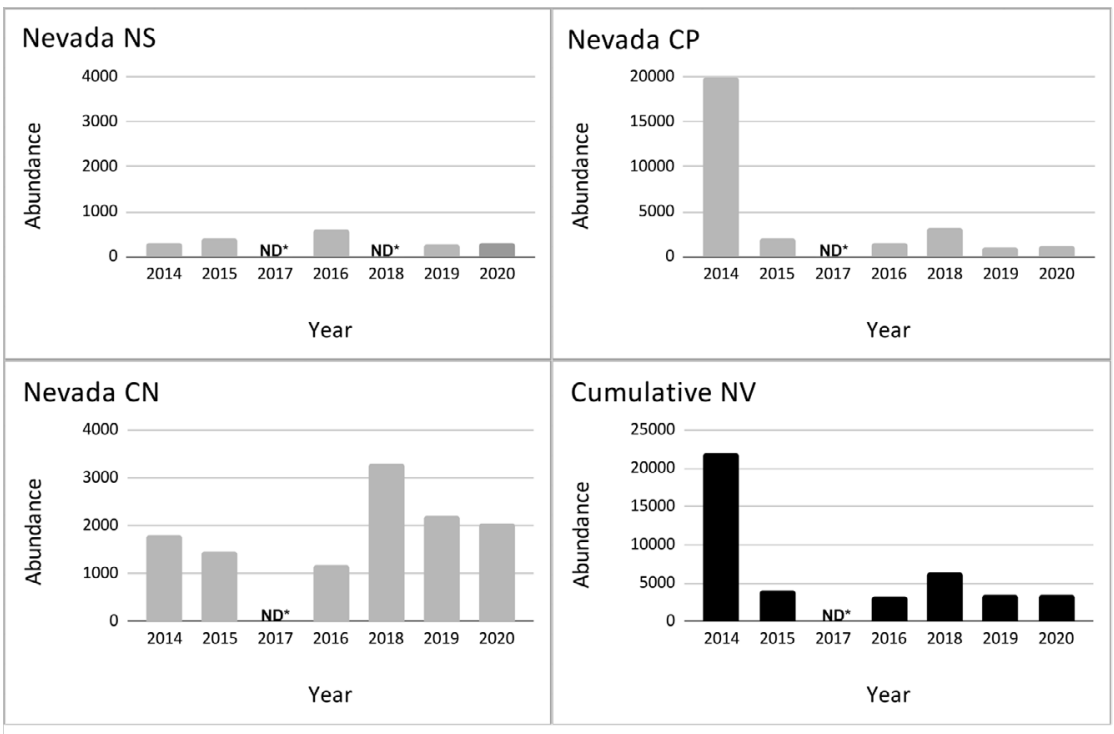

\section{CA Macroplot 1}

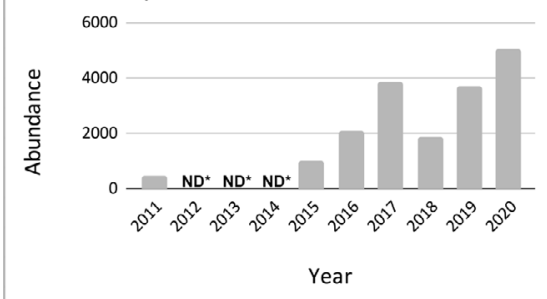

\section{CA Macroplot 3}

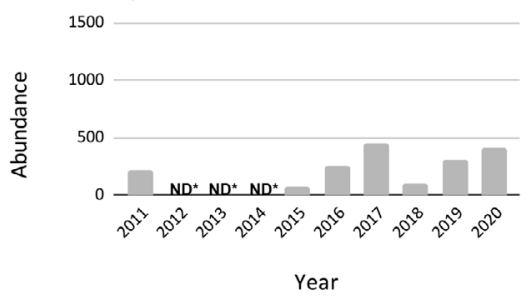

\section{CA Macroplot 5}

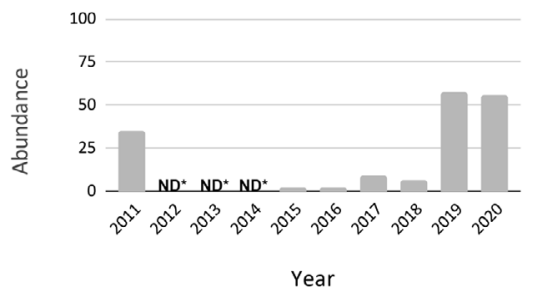

\section{CA Macroplot 2}

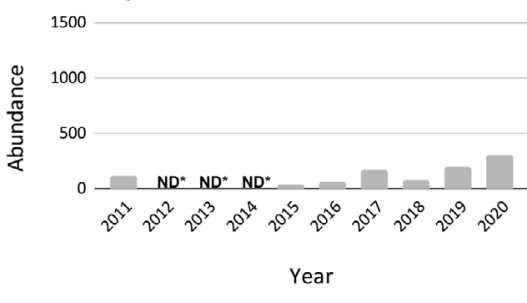

\section{CA Macroplot 4}

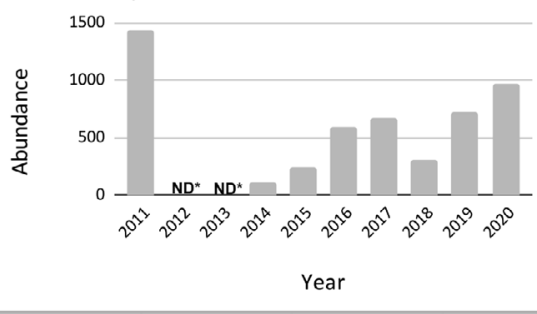

\section{Cumulative CA}

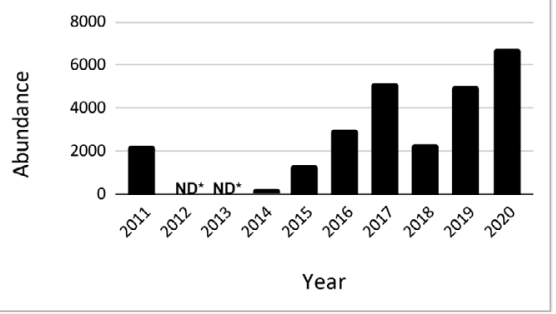

Figure 4. Abundance of Amargosa niterwort clumps in each macroplot and cumulative abundance for NV and CA for all monitoring years. $* \mathrm{ND}=$ No data 
NS increased between 2015 and 2016 following the same trend as the CA macroplots, but at both $\mathrm{CP}$ and $\mathrm{CN}$, abundance declined slightly over the same time period. In contrast to the CA macroplots, abundance at $\mathrm{CP}$ and $\mathrm{CN}$ increased in 2018 relative to 2017 and declined in 2019 (NS was not measured in 2018). In Nevada, the CN and NS macroplots where belt transects were used, did not show significant change in clump abundance (Table 3A).

\section{Phenology and Seed Production}

Data collected during phenology monitoring indicate that plants of $N$. mohavensis begin to go dormant as early as August, but are primarily dormant between the months of November and January (Fig. 3). New growth typically begins to emerge from underground rhizomes in February and plants are green and at maximum growth in July. Flowers have been reported in the months of May, June, and July and seed collections were made on August 1, 2010 (10 seeds total from 30 sampled individuals), June 27, 2011 (51 seeds from 34 sampled individuals), and July 17, 2020 (94 seeds from 24 individuals). The seed collections in 2010 and 2011 were collected in bulk, so we could not determine how many sampled individuals contributed to seed production. Seed production appears to be relatively low, with few filled seeds being collected across all three years. There are a total of 155 seeds present in the California Seed Bank, collected from 68 sampled individuals, (average of 2.3 seeds per sampled individual).

\section{Climate}

Five of the nine monitoring years of $N$. mohavensis were drier than the 30-year normals for annual precipitation on lower Carson Slough (Fig. 5). California experienced a significant drought between 2012 and 2015; this is reflected in weather conditions reported in PRISM (2020). There was above average precipitation between 2016-2017, and in 2019. The driest year recorded since monitoring began was in 2012. Precipitation was similar to the 30 -year normals in 2011 and 2020. Temperatures were above average between 2012-2018, with the first four years having below average precipitation, followed by two years of above average precipitation (2016 and 2017; Fig. 5).

Abundance was not significantly correlated with any climate variables for California or Nevada (Table 3). Abundance of N. mohavensis in California had a slightly positive but insignificant correlation with precipitation and a negative but insignificant correlation with mean maximum temperature. Abundance in Nevada had a slight negative correlation with precipitation, but this was also not significant (Table 3). Macroplots $\mathrm{CP}$ and $\mathrm{CN}$ in Nevada occur below Crystal Reservoir, and it is likely that water release from the dam is the dominant factor driving abundance at these macroplots. Macroplot NS in Nevada is not below Crystal Reservoir and shows an increase in abundance in years with increased precipitation and has increasing and decreasing trends that are similar to the lower Carson Slough occurrence in California.

\section{Threats}

Prior reports have documented direct impacts to plants and habitat from off-highway vehicle (OHV) use. These threats had largely been abated or reduced due to fencing along Ash Meadows Road at lower Carson Slough (USFWS 2007) and exclusion of OHVs from AMNWR. However, recent surveys have revealed that OHV use continues to be a direct 


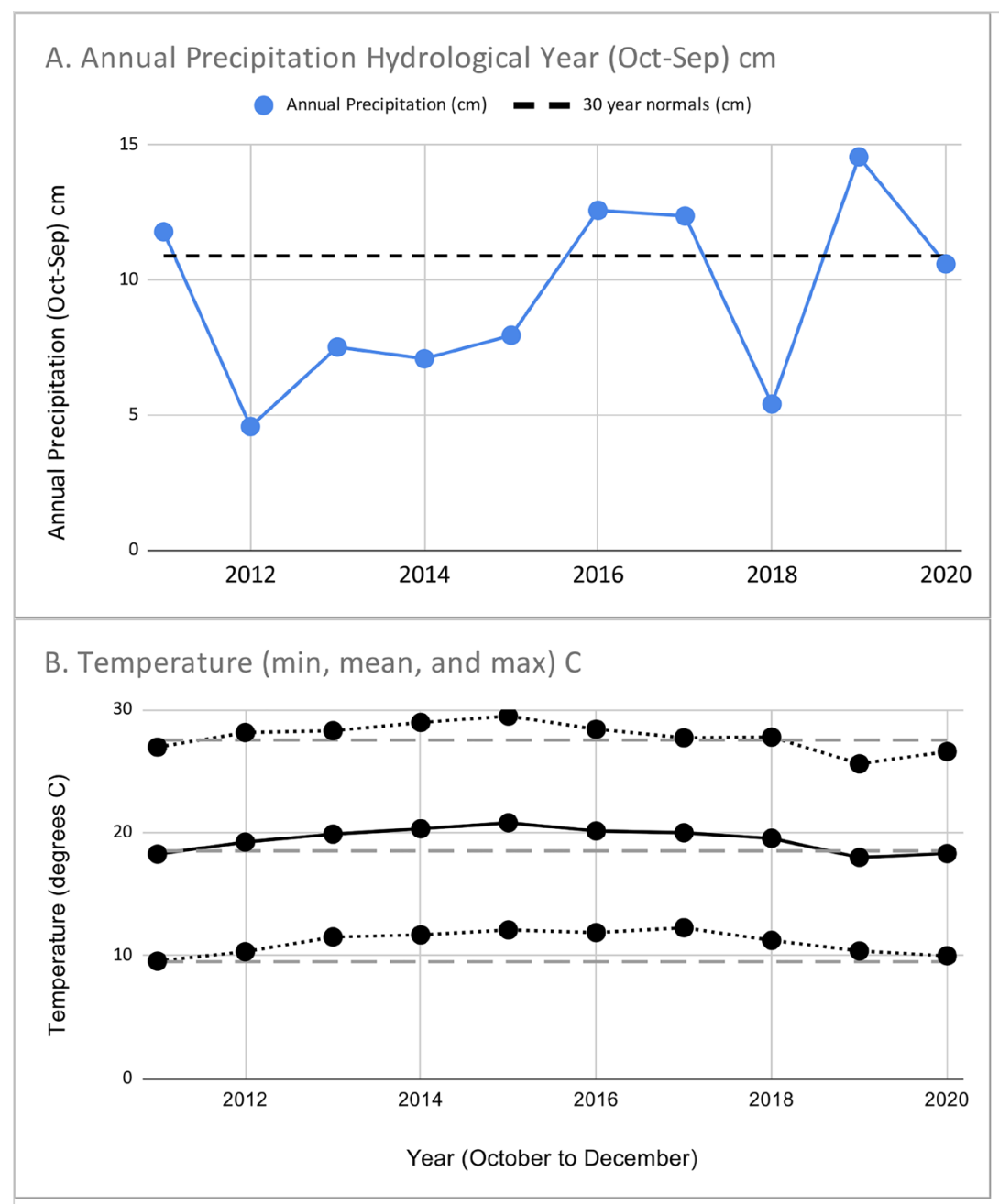

Figure 5. A. Annual cumulative precipitation Oct-Sep (cm) across monitoring years between 2011 and 2020, 30-year normals (1981-2010) are included as a dashed line. B. Annual mean daily temperature (solid line) with minimum and maximum temperature (dotted lines) $\left({ }^{\circ} \mathrm{C}\right)$ for the 2011 to 2020 monitoring period, 30-year normals are included as a dashed line.

threat to the $N$. mohavensis in California due to damaged and down fencing. Fencing was observed to be down on multiple instances in 2017 and 2018 and new tire tracks were noted when the fence was down (Fig. 6). Given the frequency with which the fence is subject to damage, OHV trespass continues to be a significant threat to the lower Carson Slough occurrence of $N$. mohavensis. Feral horses were also observed on lower Carson Slough in 2018 and 2019 and evidence of their tracks and droppings have been observed near occupied $N$. mohavensis habitat. Feral horses have been successfully excluded from AMNWR using fencing.

Decline in groundwater resources and alteration of hydrology are the most significant threats to $N$. mohavensis populations, and to other endemic species of plants and animals that 


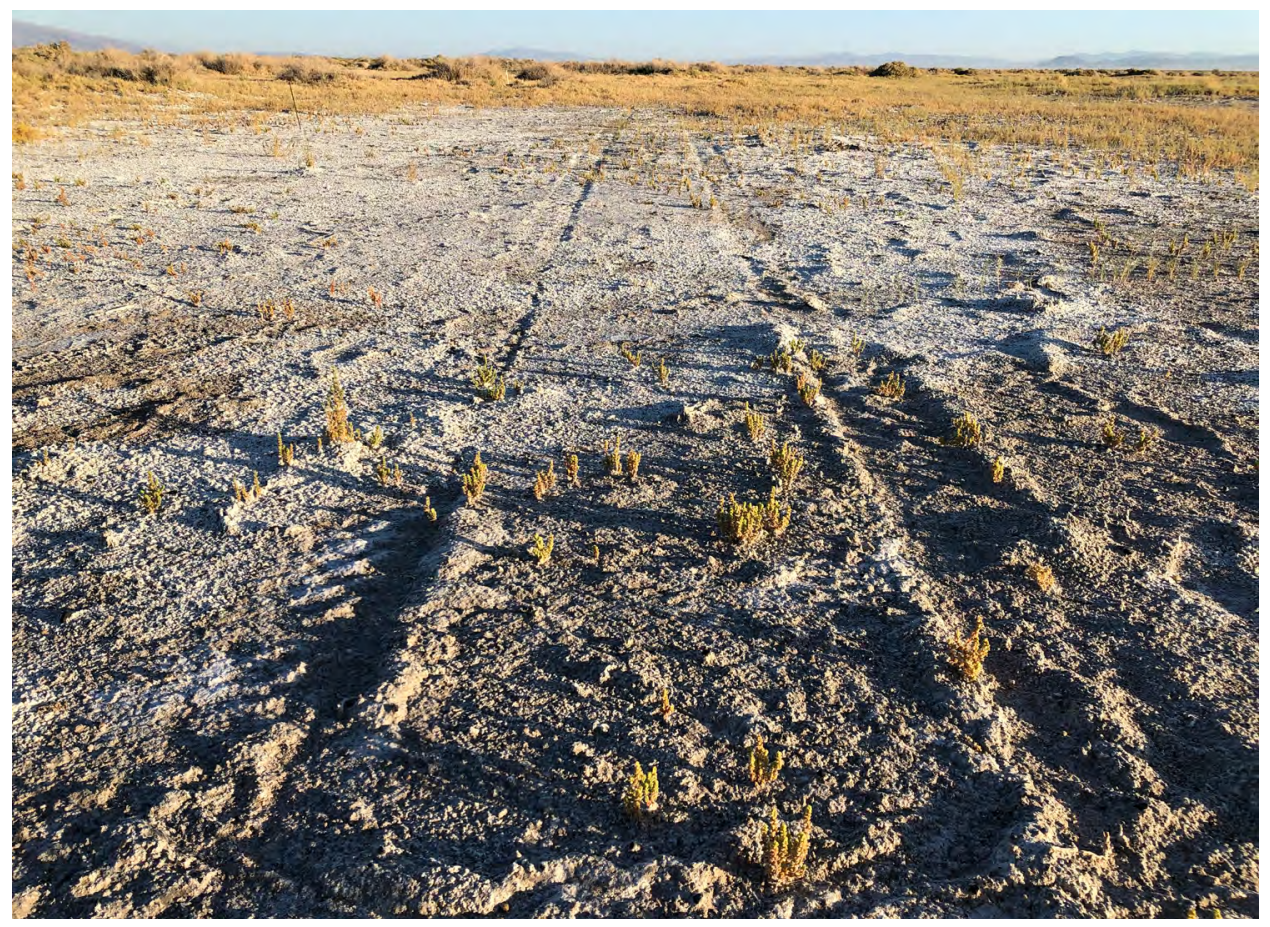

Figure 6. Off highway vehicle incursion into Amargosa niterwort habitat at lower Carson Slough, Inyo County, California.

occur in groundwater dependent ecosystems. The northern Amargosa Valley groundwater basin, comprised of the Amargosa River Valley at the river's headwaters in Nevada, to the California-Nevada state line is over-allocated (Zdon and Associates, Inc. 2014; Partner Engineering and Science, Inc. 2020). Groundwater usage within the northern Amargosa River basin has steadily increased over the past 25 years, and significant impacts to groundwater resources could result if right holders fully exercise their water rights (Partner Engineering and Science, Inc. 2020). Groundwater monitoring from the California State Line to Tecopa, California, indicates there is a slow but continual groundwater decline, primarily from pumping within the Nevada portion of the basin (Partner Engineering and Science, Inc. 2020). In AMNWR, management of Crystal Reservoir water levels, including periodic water releases and leakage from the earthen dam, result in inconsistent water supply to the alkali meadows below the dam. Long-term trends in groundwater withdrawal may reduce spring flow to the systems that feed the alkali habitats that support $N$. mohavensis and other endemic species in the region (Belcher et al. 2016).

\section{DISCUSSION}

\section{Distribution and Abundance}

At lower Carson Slough CA macroplot 1 accounts for $70 \%$ of all clumps within the monitoring plots and is located in an area with the highest density of plants. There has been an increase in the number of clumps reported from CA macroplot 1 since 2011, with a sig- 
nificant increase in 2016. There is significant variation in the abundance of $N$. mohavensis clumps between years in California (Table 2). However, there are consistent trends across macroplots (increase or decrease) relative to the prior year starting in 2015, indicating that factors influencing the increase or decrease in the number of clumps is similar across the population. This pattern is not shared in Nevada, except for macroplot NS, which shares similar trends of increasing or decreasing abundance between years as California. Aside from the significant decline at macroplot CP in Nevada from 2014 to 2015, the plots in Nevada have been relatively stable with few significant changes between years. Two of the Nevada macroplots are directly downstream of Crystal Reservoir (CP and $\mathrm{CN}$ ) and are affected by release rates of water from the dam. While it is likely that surface flow and changes in groundwater in the region are influencing changes in abundance at most of the monitored sites, the macroplots below Crystal Reservoir are buffered by a year-round source of water from the dam.

Abundance is not correlated with the climate variables we examined, and changes in abundance may have more to do with changes in subsurface groundwater flow or spring discharge. Groundwater levels are thought to be the most significant driver of $N$. mohavensis habitat quality. Data on groundwater availability near macroplots has not been analyzed together with $N$. mohavensis data, but groundwater is monitored at both AMNWR (spring discharge rates and groundwater well levels; USFWS 2020) and the lower Carson Slough (piezometers). Analysis of groundwater level impacts on $N$. mohavensis abundance and reproduction are needed to provide a greater understanding of the observed patterns of inter-annual variation in abundance and population trends. In addition, monitoring by Miller (2020) in Nevada found evidence that reproduction (flowering and/or fruiting) was strongly and significantly positively correlated with cumulative annual precipitation, and strongly and significantly negatively correlated with all temperature values. While the climate variables we examined do not appear to influence abundance significantly, it may impact important factors related to long-term population viability such flowering and seed production. The relationship between climate and reproduction should be further investigated. No other plant traits measured in the Nevada monitoring program were significantly correlated with climate variables that were examined.

\section{Threats}

Ameliorating threats range wide is essential for the recovery of $N$. mohavensis, particularly in California, which has the most abundant population and the most recorded threats. In the prior five-year review (USFWS 2007), it was reported that threats such as $\mathrm{OHV}$ incursion have been halted. However, ongoing surveys have revealed that habitat at lower Carson Slough remains vulnerable to disturbances from OHV due to its proximity to State Line Road, which bisects the population and downed fencing. Off-highway vehicle activity may cause soil compaction, damage plants and underground rhizomes, alter habitat quality, and introduce invasive plants (Switalski 2018). Ensuring that there is a consistent source of funding for fence construction and repair will be important to reducing this threat. Regular monitoring of the fence status is required to ensure that threats such as OHV and feral horses do not continue to impact plants. Further, it is likely that plants on the south side of the road have been impacted by improvements to State Line Road which is now elevated above ground level and may act as a berm-like barrier impeding water-flow from north to south. CA macroplot 5 has the fewest number of clumps that were counted within 
the monitoring period. Population size of CA macroplot 5 ranged from two clumps in 2015 and 2016 to 58 clumps in 2019. An effort should be made to ensure that surface and subsurface flow of water is able to pass across the road and to map and monitor additional areas that contain plants on the south side of the road, as plants occur up to $2 \mathrm{~km}$ south of State Line Road (Fig. 2).

Groundwater overdraft has been identified as the single most significant threat to the long-term persistence of $N$. mohavensis (USFWS 1990; 2007; 2020; Belcher et al. 2016). Regionally, monitoring of the status of the carbonate aquifer that is the source of spring water throughout the range of $N$. mohavensis is critical to tracking the long-term effects of groundwater withdrawal on spring ecosystems. Sources of groundwater extraction that are known to affect groundwater levels within the region include agriculture in the Amargosa Valley, Nevada (e.g., alfalfa production and a dairy farm) and agriculture and residential development in Pahrump Valley, Nevada (Parker et al. 2021). Local groundwater monitoring collected within and around $N$. mohavensis populations should be analyzed together with abundance data in California and Nevada in order to improve understanding of how variation in subsurface water availability affects these populations. Inter-annual variation, including significant increases and decreases in abundance within macroplots between years are not correlated with the climate variables we examined including precipitation, thus understanding how groundwater discharge and variation in surface and subsurface flow within $N$. mohavensis habitat will be essential to understanding population trends in the future.

\section{Cross-Border Initiative}

A working group for $N$. mohavensis was established in 2018 and consists of agencies and stakeholders from California and Nevada including BLM, California Botanic Garden, and the USFWS. The working group has convened regular meetings to facilitate data sharing, discussion of threats, monitoring results, priority management actions and considerations, and to evaluate future research and management objectives. Establishing communication across state boundaries is essential for the long-term conservation of a highly imperiled cross-border species like N. mohavensis. The habitat at lower Carson Slough on BLM land in California is an extension of the extensive wetland ecosystem included within the AMNWR, thus research objectives and management considerations in CA likely involve ecological processes and management considerations occurring at AMNWR. As a result of convening the working group, we have compiled and analyzed our combined data to increase our understanding of $N$. mohavensis. We have also identified research priorities that will aid in conservation strategies including investigating how groundwater pumping could affect salinity and water availability at occupied sites, and further investigating plant reproduction, including pollination and seed set. Additionally, a form of herbivory (webbing produced around stems) has been observed at sites in California and Nevada and requires further research to understand any associated impacts to the populations (Fig. 7). Some of this work is ongoing (e.g., reproductive biology studies), but increasing understanding of the relationship between groundwater availability and current patterns of abundance and distribution is of the highest priority for the long-term conservation of this species.

\section{ACKNOWLEDGMENTS}

We would like to thank John Willoughby who designed the monitoring protocol that is currently being implemented in California and Nevada and Karen Tanner who was 


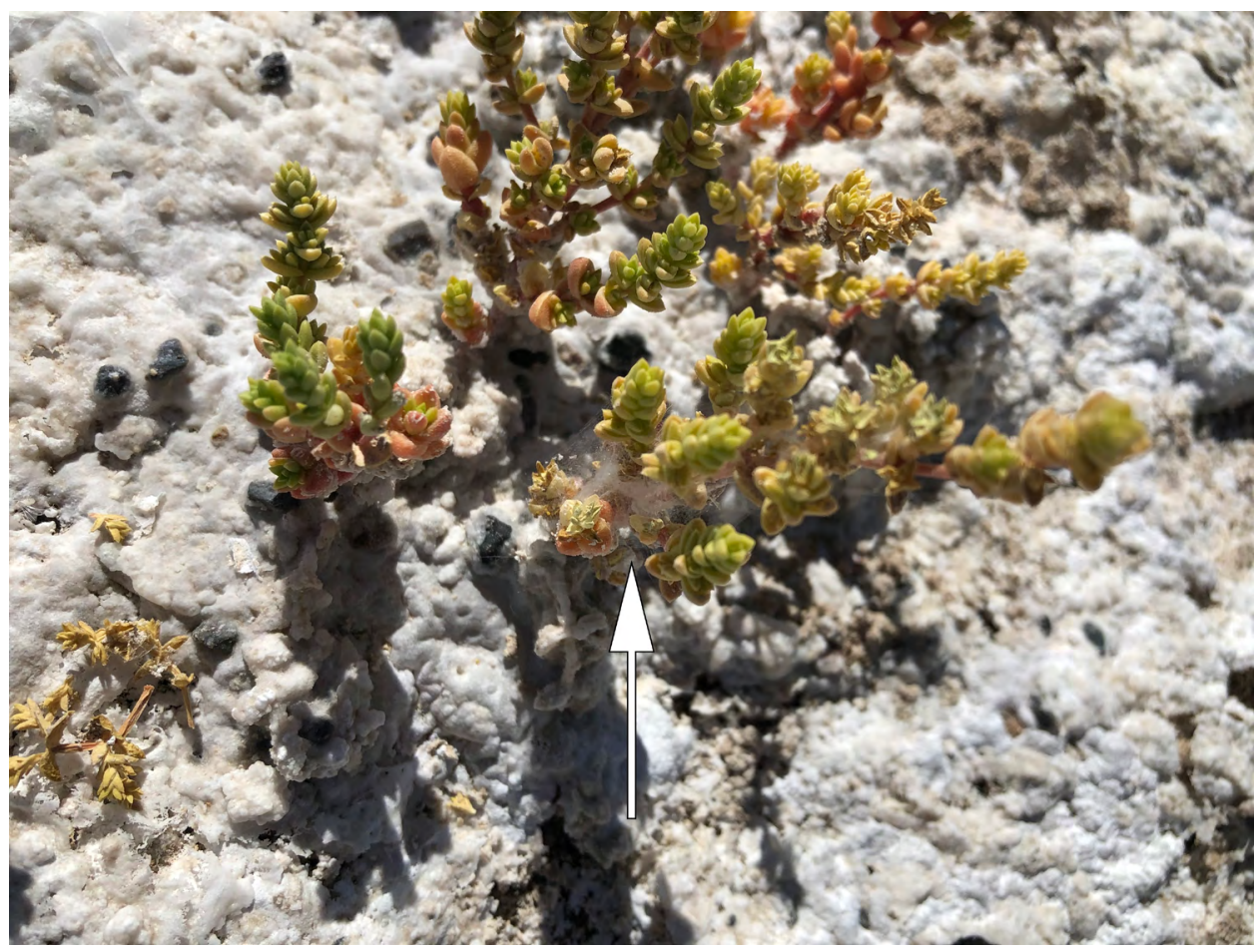

Figure 7. Webbing observed around stems of Amargosa niterwort.

instrumental in development of the protocol for AMNWR. We also thank Jennifer Wilkening (USFWS) for her support in conception of this research, and Lara Kobelt for providing survey data and assisting with monitoring in California. Kobelt and Wilkening are founding members of the Amargosa niterwort Working Group. We thank the numerous field assistants who have collected data monitoring the California and Nevada populations. Funding was provided by the BLM, California Botanic Garden, and U.S. Fish and Wildlife Service including Traditional Section 6 Grant (P1886001). The Amargosa Conservancy assisted with data collection in growth plots between 2012-2016. We thank Cheryl Birker, Carolyn Mills, and Kim Schaefer for assistance with data collection and seed collection and processing. Patrick Donnelly reviewed an early draft of this manuscript and provided useful comments. We thank four reviewers who provided useful comments and greatly improved this manuscript.

\section{LITERATURE CITED}

Belcher, W. R., D. S. Sweetkind, C. C. Faunt, M. T. Pavelko, and M. C. Hill. 2016. An update of the Death Valley regional groundwater flow system transient model, Nevada and California. Available from: https://pubs.er.usgs.gov/publication/ sir20165150 (November 2020)

Consortium of California Herbaria (CCH2). 2020. $\mathrm{CCH} 2$ data portal. Available from: https://www.cch2.org/portal/index.php (June 2020)

California Natural Diversity Database (CNDDB). 2020. California Department of Fish and Wildlife, RareFind 5. Available from: https://www.wildlife.ca.gov/Data/CNDDB/ Maps-and-Data (July 2020) 
California Native Plant Society (CNPS). 2020. Inventory of Rare and Endangered Plants (online edition, v8-02). California Native Plant Society, Sacramento, CA. Available from: http://www.rareplants.cnps.org (November 2020)

Center for Plant Conservation (CPC). 2017. CPC best practices for collecting seeds from wild rare plant populations. Available from: https://www.saveplants.org/cpc-bestpractices-collecting-seeds-wild-rare-plant-populations (November 2020).

Hasselquist, N. J., and M. F. Allen. 2009. Increasing demands on limited water resources: consequences for two endangered plants in Amargosa Valley, USA. American Journal of Botany 96:620-626.

DeFalco, L., S. Scoles-Sciulla, and E. Bermgauard. 2017. The role of salinity tolerance and competition in the distribution of an endangered desert salt marsh endemic. Plant Ecology 218:475-486.

Johnston, S. C., and T. A. Zink. 2004. Demographics and ecology of the Amargosa niterwort (Nitrophila mohavensis) and Ash Meadows gumplant (Grindelia fraxinopratensis) of the Carson Slough Area. Report to the Bureau of Land Management.

Martin, P., E. Paulson, and R. Graham. 2013. Geographically disjunct populations and widespread genets in an endangered halophilic plant, the Amargosa niterwort ( $\mathrm{Ni}$ trophila mohavensis). Conservation Genetics 14:953-962.

Miller, A. 2020. Amargosa niterwort (Nitrophila mohavensis) monitoring results, 20102020, California and Nevada. Unpublished report for Ash Meadows National Wildlife Refuge, Amargosa Valley, NV, USA.

Munz, P. A., and J. C. Roos. 1955. California Miscellany III. Aliso 3:112-114

NatureServe. 2020. Nitrophila mohavensis, NatureServe Explorer 2.0. Available from: https://explorer.natureserve.org/Taxon/ELEMENT_GLOBAL.2.133016/Nitrophila_mohavensis (June 2020)

Parker, S. P., A. Zdon, W. T. Christian, B. S. Cohen, M. Palacios Mejia, N. S. Fraga, E. E. Curd, K. Edaltai, and M. A. Renshaw. 2021. Conservation of Mojave Desert springs and associated biota: status, threats, and policy opportunities. Biodiversity and Conservation 30:311-327.

Partner Engineering and Science, Inc. 2020. Amargosa State of the Basin Report, Amargosa River Basin, Inyo and San Bernardino Counties: Report prepared for the Amargosa Conservancy, Shosone, CA, USA.

PRISM Climate Group. 2020. Northwest Alliance for Computational Science \& Engineering (NACSE), Oregon State University, Corvallis, OR, USA. Available from: http://www.prism.oregonstate.edu (October 2020)

Tanner, D. A., N. F. Boehme, C. M. Clark, and J. P. Pitts. 2012. The Contributions of Insect Pollinators to the Reproductive Fitness of 12 Rare Plants on Ash Meadows National Wildlife Refuge Final Report. Available from: https:/ecos.fws.gov/ServCat/DownloadFile/56734?Reference=55957 (August 2020)

Switalski A. 2018. Off-highway vehicle recreation in drylands: a literature review and recommendations for best management practices. Journal of Outdoor Recreation and Tourism 21:87-96.

U.S. Fish and Wildlife Service (USFWS). 1983. Endangered and Threatened Wildlife and Plants: Proposed Endangered Status and Critical Habitats for Seven Plant and One Insect Species in Ash Meadows, Nevada and California. Available from: https://ecos.fws.gov/docs/federal_register/fr756.pdf (June 2020)

U.S. Fish and Wildlife Service (USFWS). 1990. Recovery Plan for the Endangered and 
Threatened Species of Ash Meadows, Nevada. Available from: https://ecos.fws. gov/docs/recovery_plan/900928d.pdf (June 2020)

U.S. Fish and Wildlife Service (USFWS). 2007. Amargosa niterwort (Nitrophila mohavensis). Five-Year Review: Summary and Evaluation. U.S. Fish and Wildlife Service, Nevada Fish and Wildlife Office. Las Vegas Nevada. Available from: https://ecos. fws.gov/docs/five_year_review/doc1864.pdf (June 2020)

U.S. Fish and Wildlife Service (USFWS). 2020. Ash Meadows National Wildlife Refuge Natural Resource Management Plan. National Wildlife Refuge System, Pacific Southwest Region, Sacramento, CA, USA.

Wetherwax M., D. H. Wilken, and N. H. Holmgren. 2012. Nitrophila mohavensis, in Jepson Flora Project (eds.) Jepson eFlora. available from: https://ucjeps.berkeley. edu/eflora/eflora_display.php?tid=34674 (November 2020)

Zdon \& Associates, Inc. 2014. State of the basin report, Amargosa River basin, Inyo and San Bernardino Counties, California and Nye County, Nevada: Report prepared for the Nature Conservancy, Pasadena, CA, USA.

Submitted 1 December 2020

Accepted 22 January 2021

Associate Editor was R. La Rosa 